\title{
The growth phenomenon: An analysis
}

\author{
Hugh G. Clarke \\ Lewis Stores Ltd., Cape Town
}

\begin{abstract}
The author maintains that growth - biological, physical, economic - is concerned with the transformation of one form of energy and matter into another. He analyses the way this energy is used and relates this to business growth. Energy utilization, entropy, transformation and maintenance costs, and the need to seek energetic efficiencies, are discussed. In his analysis of the mechanics of growth, and especially the sigmoid curve, the author shows with examples that a characteristic of growth is that success tends to develop the seeds of failure: that one characteristic of normal developmental growth is the restriction imposed on that growth by the organisms or organization's genus. Business failure is seen as inevitable as the 'natural' ageing process and the author examines critical periods in which the business may fail. He concludes by examining strategies for prolonging business 'life' and urges greater multi-disciplinary research into the life process.
\end{abstract}

S. Afr. J. Bus. Mgmt. 1982, 13: 176-182

Die skrywer beweer dat groei - biologies, fisies, ekonomies - die transformasie van een vorm van energie en materie na 'n ander behels. Hy ontleed die manier waarop hierdie energie gebruik word en bring dit in verband met sakegroei. Energiebenutting, entropie, transformasie- en onderhoudkoste en die noodsaaklikheid om energie-doeltreffendhede te soek, word bespreek. In sy ontleding van die groeimeganika, en veral die sigmoïde kurwe, toon die outeur met voorbeelde aan dat dit ' $n$ eienskap van groei is dat sukses neig om die saad van mislukking in te hou: dat een eienskap van normale ontwikkelingsgroei die beperking-op-groei is wat die betrokke organisme of organisasie se aard daarop plaas. Die mislukking van sake-ondernemings word gesien as net so onvermydelik soos die 'natuurlike' verouderingsproses en die outeur ondersoek kritiese tydperke waarin ondernemings mag misluk. Hy sluit af met ' $n$ ondersoek van strategiee waardeur die 'lewe' van sake-ondernemings verleng kan word en pleit vir meer multi-dissiplinêre navorsing oor die lewensproses.

S.-Afr. Tydskr. Bedryfsl. 1982, 13: $176-182$

\section{The growth phenomenon}

Why do businesses or products fail? What makes them succeed? These two questions are of tremendous importance to the marketing man. Yet, strangely, marketing theorists have paid relatively little attention to what can be called 'the growth phenomenon'.

This is especially surprising when one considers the number of new business ventures and product launches that take place each year throughout the world - and which end in failure. Even well-established, successful giants are not immune from business failure. Of the 20 largest companies in the United States $\mathbf{4 0}$ years ago, only two are still among the first 20 in size. Of the 100 largest companies in the United States 25 years ago, almost half have disappeared or declined substantially from their peak. ${ }^{1}$ This paper examines the mechanics underlying growth and suggests the need for a new analysis.

\section{The growth process}

What is growth? In a nutshell, growth - biological, physical, economic - - is the transformation of one form of energy and matter into another. Plants take energy from the sun, air and soil and transform it into plant tissue; animals convert energy from plants or other animals into physical tissue; business organizations take raw or partly processed resources and work on these to get value-added products or services.

Growth is most spectacular and rapid in early life. However, this early rapid growth soon slows, which is not surprising when one considers the amount of increasing energy that needs to be expended to maintain a constant growth rate.

If company sales double every year (in thousands) as follows: $10,20,40,80,160,320,640$, etc., one soon reaches a point where restricting factors - lack of resources, space, inefficiencies of operation, etc. - result in diminishing marginal returns and the growth rate slows.

The initial rapid growth and subsequent slow-down is well depicted by the sigmoid or S-shaped curve so well known to marketers (see Figure 1). Its application to the economy as a whole is shown in Figure 2. We can apply this growth curve to every aspect of the business, for example:

- Career development (individual growth in the work situation):
H.G. Carke

68 Dean Street, Newlands 7700, Republic of South Africa 


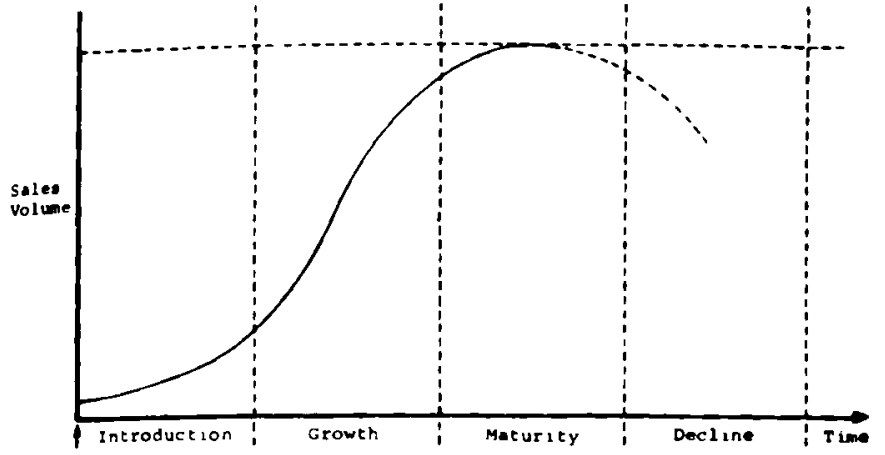

Figure 1 Typical (product) life cycle
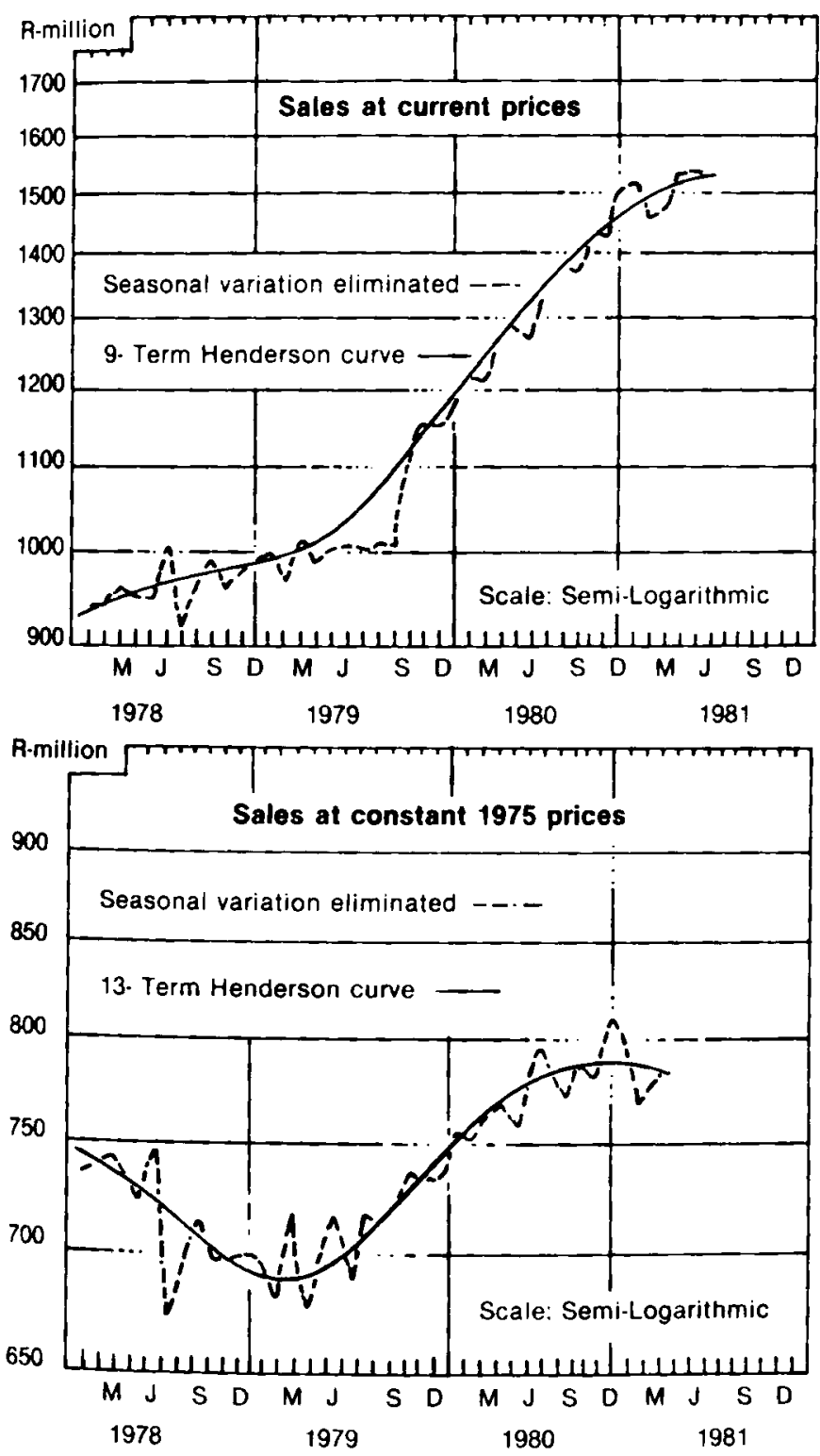

Retail sales in cash ferms are not growing at the same rate as they were last year and in real terms are levelling out, as can be seen from these graphs prepared by the Department of Statistics. At current prices retail sales in the three months ended May are estimated at R1 519.5 million a month, which is an increase of $1,6 \%$ on the previous quarter. However, measured in 1975 prices. relail sales in the March-May quarter were down $1.5 \%$ on the previous three months.

Fhure 2 Retail sales in South Africa 1978 - 1981 (Reproduced from The Argus, May 26, 1981, p.31)

- Company growth (from sole trader to multi-national);

- Consumer growth (perhaps based upon the consumer life cycle);
- Product growth (launch, acceptance, growth, maturiiy, etc.);

- Personal growth (from physiological and security needs to self-actualizing);

- Leadership growth (through the various styles of management).

\section{Characteristics of the growth curve}

The S-curve of growth may be divided into two principal segments: the first of increasing slope, designated the selfaccelerating phase; the second of decreasing slope designated the self-inhibiting phase. The shape of the curve may accordingly be said to be moulded by two opposing forces: growth-accelerating and growth-retarding.

In the growth phase of, say, a product launch, opportunities look good. Sales zoom off. Trading profits are high. The cash till keeps ringing merrily. The coffers are full. However, the elation and euphoria that goes with this success is (relatively) short-lived. Much to the annoyance of the marketing manager, other competitors enter the market chasing the lucrative profits. As more competitors enter the market, price-cutting becomes the order of the day as a tactic to hold or increase market share. Profits start to slide . . . it's a well-known story.

In technical terms, this building-up phase of growth is called anabolism; the breaking-down, or giving-up phase is catabolism; the combination of the two is metabolism. In early life, anabolism (growth) is predominant; in later life, there is a decrease in anabolism - a reduction in healthy life-giving 'tissue' - and ageing takes place.

The question is: why is there an inevitable decline with age? Why do growth companies stop growing; 'Blue Chips' stagnate; products fail? Why is there the rise and fall of industries and even of nations as economic powers? Alternatively: why can't there be a perpetual renewal of the body? Why can't organizations survive through continuous adaptations? Why can't one extend the product life cycle for ever?

\section{Reasons for business decline}

Three reasons can be put forward for business (or product) failure:

The first reason for business decline concerns 'energy utiliza tion'. To convert a company's inputs (man, machines, materials, etc.) to outputs uses energy which has to be paid for. This word 'energy' is used in its broadest sense - power for machines, cost of human effort, etc. Indeed, any system, business or otherwise, has two energy costs associated with it:

(i) the cost of transforming energy to ensure growth (productivity).

(ii) the cost of maintaining the organization (maintenance).

The key word in 'energy transformation' is efficiency. Organizations (and organisms) that are efficient in their use of energy resources survive. Their cost efficiency in the use of resources gives them the competitive edge - i.e. greater profit margins.

This need for efficiency is a fundamental law of nature. and of growth in general. So much so that certain authors have 'borrowed' management principles relating to growth 
from nature, e.g. Louis A. Allen' talks of the 'Principles of Conscious Selection':

Those organisational forms will tend to dominate

which can best select and adapt to their own use the

most successful characteristics of their own and com-

peting forms. (A form of Darwinism.)

Compare that quotation with the Law of Recapitulation in Biology which suggests: 'Those forms which are most efficient have the least need to change or adapt to the environment'. The Pick 'N Pay Hypermarkets (warehouse-type operation) are demonstrably more efficient in distributing consumer goods than their supermarkets - as reflected by their overall lower end prices and greater total profitability. Yet, Hypermarkets (as a business form) are only more efficient where there are large consumer concentrations and mass markets. They would be out of place, uneconomic, in the rural areas where the population is dispersed.

In seeking efficiencies to ensure growth the businessman must continuously strive to find better answers to the following types of questions: Is there any way I can improve my product (value analysis engineering); lower my production or procurement costs (production techniques; negotiations skills); increase productivity (mechanization and automation; work study); improve operating efficiencies (electronic aids; clerical assessment measures), etc.?

Unfortunately, this questioning does not always take place - the growth process is not understood by many marketers who seem hell-bent on doing more of the same old things, but at a faster and more frenetic pace. It reminds one of the classic story of two Monte-Carlo rally drivers who find themselves on a lonely Alpine pass, all but blinded by heavy snow and fog. The driver asks his navigator: 'How are we doing?' 'Well', comes the answer, 'I don't know where we are, but we're making excellent time'. Truly, this is the way to extinction.

Fact! There is a large gap in many a manager's knowledge of the growth process; of how the evolutionary and maturation process works; of how to replace ageing and dying structures with new and possibly better ones; of how to maintain the organization in a young and dynamic state despite the ageing and decline of its constituent members (e.g. leaders and workers); and, how to cope with change.

A second reason for business decline concerns the 'natural' ageing process. In the same way that within an individual there is a loss of skin elasticity, reduction in chemical reactivity, hardening of the arteries and of related vital tissues, so in business there are similar symptoms of old age and decline, for example, static organization structure, little use of the latest technology, inflexible authority structure, virtually no research and development, inadequate situational leadership style, etc.

Time affects the organization life cycle, from birth to death, and there are many critical periods when the business may fail, namely:

'Birth' - will the organization survive beyond year one?

'Puberty' - will the organization survive the spurt of sudden growth and the demands made on its limited resources? (e.g. cash flow problems)

'The Maturity - how does the company compare and Phase' compete with its more vigorous and younger competitors?

Unless the manager is aware of the problems likely to be encountered as the organization grows and has worked out contingency plans to deal with them, the company will age much more rapidly than it need. Typical early warning signs of 'ageing' and early business failure include: decline in company sales and profits; increasing level of administration and selling expenses; reduction in number of customers; increasing product obsolescence; worsening cash flow and increasing commitments; departure of key personnel, and so on.

A third reason for business failure concerns entropy. According to the second law of thermodynamics, anything left to itself runs down. A motor car rusts, a shop gets dirty, a salesman loses his enthusiasm, a business loses momentum. (That's why managers are employed, incidentally, to continuously promote inputs and rejuvenate life.) In business, as elsewhere, life is growth. To quote Amiel, ${ }^{2}$ the French poet:

The stationary condition is the beginning of the end.

If your organization is not growing, or is growing at a rate slower than the industry as a whole, it faces an inevitable decline. The implications of this assertion for a company are apparent from Figure 1 (see dotted line) where there is no growth.

\section{The mechanics of growth}

All this does not answer our earlier question: why cannot the organization carry on adapting and regenerating itself? The answer is that according to biological theory, all organisms behave in accordance with a predetermined design. What you do depends on what you are. Fichte, ${ }^{3}$ the German philosopher noted: 'The type of philosophy a man adopts depends on the type of man he is' (behaviour determines attitude?). Alexander ${ }^{4}$ noted that 'function determines form'; Chandler ${ }^{5}$ that 'structure follows strategy'; Heidegger ${ }^{6}$ that 'Essence preceeds existence', etc. They were all saying basically the same thing: that one characteristic of normal developmental growth is the restriction imposed on that growth by the organism's (or organization's) genus. In short, one works within a limited framework.

To be sure, some regeneration is possible, cosmetic or otherwise. Theodore Levitt ${ }^{7}$ showed how to do this for the product life cycle. The business can be modernized, given a face-lift so to speak: a new management team brought in, or there is a fresh injection of capital. But this does not represent a complete renewal of the total organization.

Indeed, if the S-curve holds true, business failure is inevitable. (Over the long term, admittedly.) For no matter how dynamic your company is right now, it contains within it, the seeds of its own destruction. Powers and size did not protect the dinosaur; the development of perfect sabre teeth did not protect the sabre-toothed tiger. Extinction is common in nature. Of the $\mathbf{8} 000$ species of mammals that have been known to exist, about 4000 have become extinct often at the peak of their evolutionary glory. A similar comment could be made of many business empires that have 
'crashed', e.g. Central Leather Company, Underwood Corporation, International Mercantile Marine, etc. ' To quote S. Brody: ${ }^{8}$

The evolutionary illustrations on how success in evolution may lead to eventual failure suggest the idea that an important characteristic of many biological processes, including growth, is that success tends to develop the seeds of failure. Everything, including growth, seems pregnant with its contrary. For instance, growth develops a condition which may first retard growth in accordance with the law of diminishing returns, then finally stops it.

Marketers would do well to take note of this caution. Henry Ford's concept of mass production and uniformity ('Any colour as long as its black') was partly stymied by the consumer's desire for variety and choice; the Swiss monopoly of the watch market with mechanical timepieces was thrown overboard by Japan's electronic wizardry; South West Africa's fishing grounds were ruined by injudicious management and over-exploitation. Success breeds success - and failure!

The Hypermarket, successful as it is now, may - with time - become a gigantic 'white elephant', a prey to its own policy of too wide a range of goods at low prices, or increased rentals and running costs and new methods of consumer shopping. The 'invincibles' are all too often vanquished - take the American motor industry, Anglo-French Concorde, the oil companies' current need to diversify. This is not just a matter of technology, market forces or environment, but often too much commitment to an outdated organizational life-style - i.e. lack of the right degree of divisionalization, departmentalization, decentralization, and so on.

Is there a connection between business growth and natural growth?

Just in case any readers take a sceptical view of the connection between the natural growth processes and business growth it is well to compare the two with a specific example. This can be done both descriptively and visually. Compare the following 'problems' that occur in the growth process:

\section{Human being}

Problem: Human body which in- Problem: As business sales volume creases with the cube of linear size, increases, the organizational strucwhile the strength of the supporting ture necessary to maintain the muscles increases with the square of growth rate changes.

linear size.

Result: The body becomes unstable Result: The organization becomes unless growth of the supporting inefficient unless there is an exmuscles is proportionately more pansion of administrative of fices; rapid than that of the body as a decentralization; development of whole. This actually occurs.

Summary: The organism changes (adapts) in form so as to remain physiologically stable. new divisions, etc. This actually occurs.

Summary: The organization changes (adapts) its structure according to the law of functional growth.9
The 'similarity' between this need for structural change during growth is shown in Figure 3.

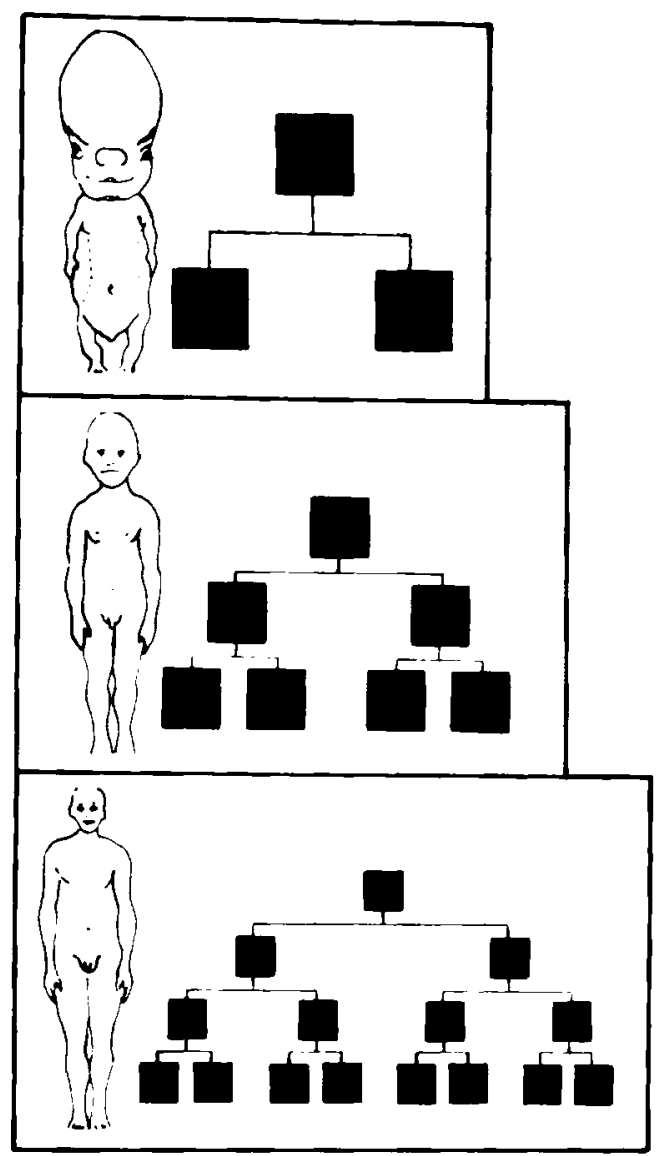

Figure 3 The similarity between the need for structural change during growth (Human anatomy from Encyclopaedia Britannica, 1962, Vol. 10, p.922)

Growth, then, in business or in physical life, depends on the 'organ' maturing in an orderly way and its structure being able to cope with expansion. Failure to develop the right structure is one of the delimiting factors of growth. This point has been noted time and again in the different disciplines. For example, sociologists have noted that social organizations expand until the communication network reaches a critical level after which there is a 'communications breakdown'; statisticians point out the need for standard behaviour: the trend towards central tendency; physicists refer to the concept of critical mass. In a word, homeostasis regulates the sociobiological environment.

In short, failure by the businessman to make the necessary changes brought about by growth, leads to organizational inefficiency with a result that company resources are not employed as profitably as they might be. Eventually, the company suffers.

\section{The growth curve: key questions and applications}

It is probably well accepted that the S-curve represents a fact of business (or any other) life. It implies that within a time framework (unspecified at the moment) the organization will grow, mature and die. Three questions therefore arise:

- What are the distinguishing characteristics in normal developmental growth in business organizations?

- Is there some integrative process binding the many business components into a harmonious whole to achieve or maintain a certain desirable state? 
- What is the relationship between the individual company and the total industry and can 'rise and fall' be predicted through time?

Let us discuss these questions individually:

\section{Distinguishing characteristics}

The growth-accelerating phase of the S-curve manifests itself early in the history of the company (or individual, or population) prior to growth-restricting forces in the environment.

Early growth tends to be at a constant percentage rate in a geometric progression - e.g. an ROl of (say) $10 \%$. Let us assess the affect of this investment over time:

\section{Initial Investment}

$\mathrm{R} 10000,00$

\section{End of Year}

\begin{tabular}{ccccccc}
1 & 2 & 3 & 4 & 5 & 6 & 7 \\
\hline 11000 & 12100 & 13310 & 14641 & 16105 & 17715 & 19487 \\
8 & 9 & 10 & 11 & 12 & 13 & 14 \\
\hline 21435 & 23579 & 25937 & 28531 & 31384 & 34522 & 37974
\end{tabular}

As you can observe, the return doubles at constant intervals. Of course, in actual fact management does not set its yearly growth targets at a constant percentage - e.g. for $10 \%$ growth each year. This figure varies according to the economic climate, inflation rate, and so on. Nevertheless, in real terms, the growth rate tends to be constant, for example, the total physical volume of goods and services in the United States has been growing at a rate of about $3 \%$ per year and the real volume of goods and services has been doubling about every 25 years. ${ }^{1, p .117}$ See Figure 4.

However, sooner or later, (and we shall discuss the time factor in the business life cycle later) restrictive forces develop in the internal or external environment to prevent such exponential growth from being maintained. Bottlenecks to growth occur: lack of skilled manpower; limitation of financial resources; lack of surplus capacity on machines;

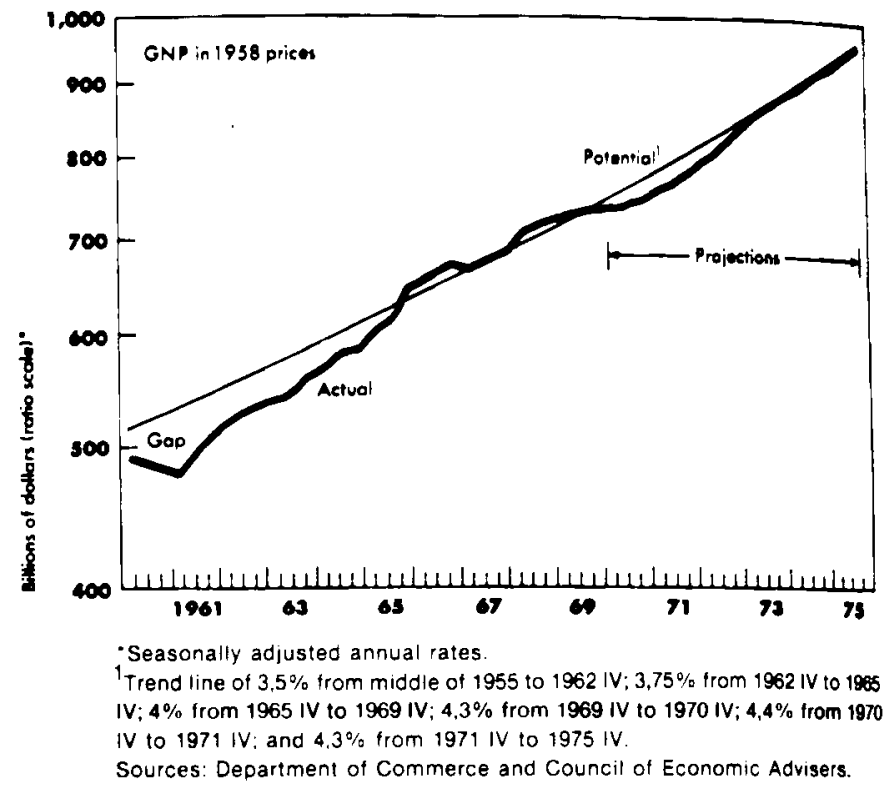

Figure 4 Growth rate of goods and services in the US (Reproduced from Robert Dorfman, Prices and Markets, 2nd ed., Prentice-Hall, Engelwood Cliffs, 1972, p.214)

overloading of the communication system; and many others.

The end result is that gradually growth changes its course from being proportional to the growth already made, to being proportional to the growth yet to be made to reach maturity. The critical or turning point in the development of any business is therefore the junction or 'major inflection' between the self-accelerating phase of growth and the self-inhibiting phase. Once this turning point is reached, the organization (or organism) starts growing more slowly and eventually shows no growth at all.

The fact that the major segments of the growth curve can be so simply described does not mean that growth is a simple process. Yet, very often it is described perhaps without the author being aware that he or she is describing growth. Take effective leadership styles, for instance. Various authorities - e.g. Reddin ${ }^{10}$ - have suggested that effective leadership styles depend on the maturity of followers. A typical illustration of this relationship is shown in Figure 5.
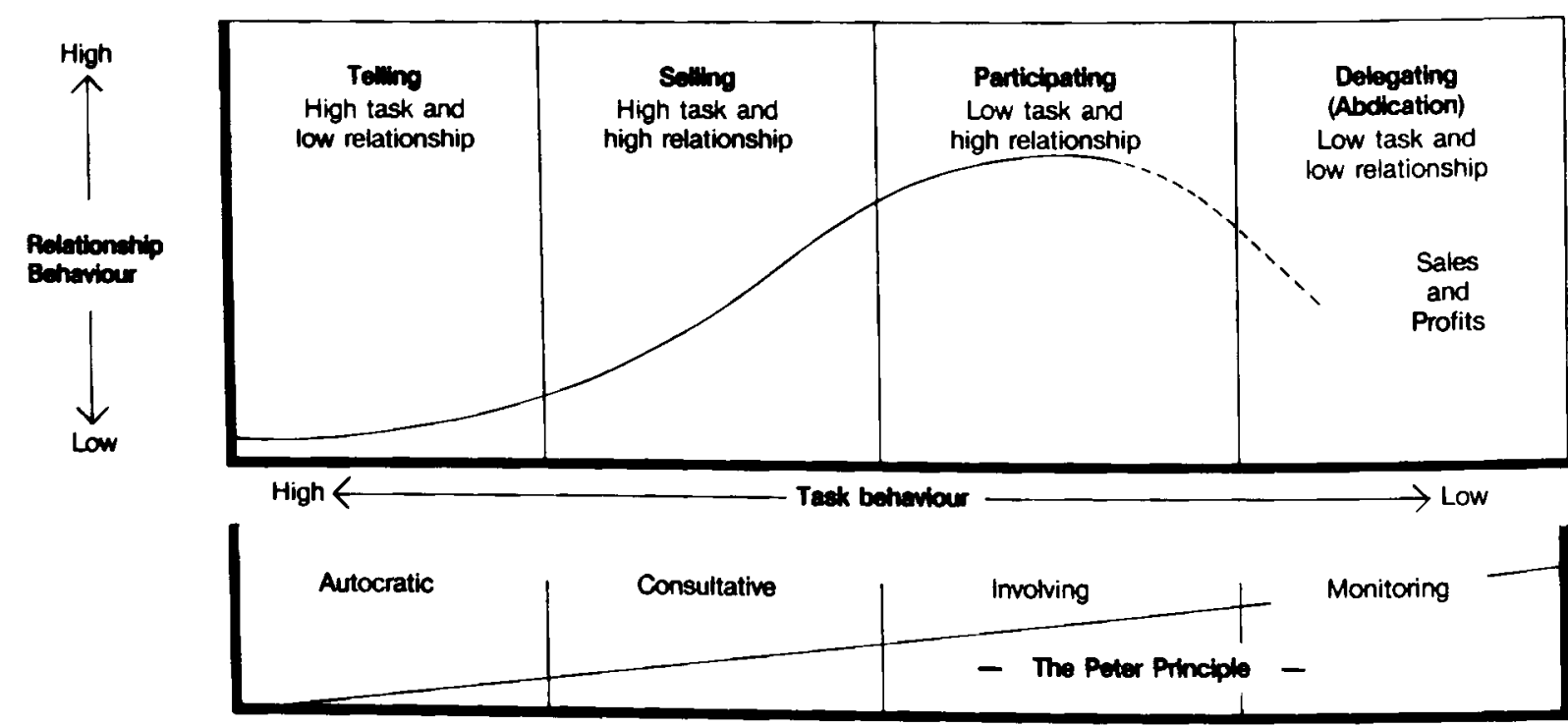
It is arguable that this 'leadership style' curve precisely matches the growth curve, i.e. in a relatively young and immature organization, leadership is autocratic and production-orientated. This ensures a high rate of initial growth (telling).

This 'style' is gradually superceded by a 'selling style' in which there is more consultation between leader and follower - if for no other reason than the leader cannot cope with everything and must start getting his subordinates involved.

This tendency accelerates in the participative phase in which more and more decisions are 'handed over' to lower levels of management. This can result in an overall weakening of leadership and a decline in sales and productivity if lower levels of management are untrained or poorly motivated.

And eventually the emphasis is on complete delegation in which decisions are taken 'down the line', thus giving younger management a chance to 'take over' from the old order.

However, injudicious decentralization (and divisionalization) are precisely what weakens the organization - e.g. lower levels of management are given responsibilities and tasks beyond their levels of competence - the Peter Principle; ${ }^{11}$ general and administration expenses creep up; divisions compete for company resources and with weakened top management, corporate policy is not strong enough to bind the various diverse elements together; overall performance suffers. It is rare to find rapid growth in any powersharing situation - be it business, political, or whatever.

Of course, this is only a scenario. Nevertheless, there seems some truth in the fact that we are witnessing the impact of the growth curve.

\section{Integrating components during growth}

We mentioned earlier that different parts of the human body develop at different rates during early embryonic growth so that the total organism remains stable. The same concept applies to business, for example, production facilities and capacities must be expanded in advance to cater for anticipated market demand; short-term cash (liquidity) requirements must be carefully balanced against long-term investments which might tie up cash; the return on capital from existing stores or departments weighed up against returns that might be realized from new stores or extensions, and so on.

Unless the business expands in an orderly and coordinated way, it 'dies' in a very short time. There are simply hundreds of instances of mismanagement; of giant companies folding, perhaps because, while they had enormous assets, their cash flow was inadequate to keep them going in the short term.

A key concept here is 'direct purposiveness'. Growth of any embryo is directive development, the production of an organism in accordance with a pre-determined design. Growth without directive purpose (as in the case of cancer cells which simply self-multiply) leads to the destruction of the organism. The same applies to the business organization.

Another key concept is 'anticipation' of future needs. In nature, such anticipation is often innate, the anticipated event being prepared for long before the event - e.g. the mammary gland is developed in anticipation of the possible birth of an infant. And this 'anticipation' is also a key requisite for business - successful businesses are known to have foresight, to anticipate, to scan the environment for change.

The question is: what is the integrative process which binds the many business functions - sales, production, finance, R. \& D., personnel, etc. - into a harmonious whole to achieve, develop or maintain a certain desirable state? The answer: 'effective leadership'.

\section{Time perspective on business life cycle}

The third question relates to time. Can we predict the rise and fall of an individual company, group of companies, or industry as a whole? Here, we are on much more dangerous ground and such predictions are fraught with danger as any commentator on Gallup Polls or statistical forecasting will tell you.

Nevertheless, if the growth phenomenon is part of a natural process, as we have claimed, some comments must be made. According to the growth theory, the ageing rate is, as a rule, directly proportional to the maturation rate: that is, the sooner 'cells' cease multiplying, the sooner they get old. (The cells in the business sense would be people, products, profits, etc.)

The maximum duration of life is about five times the period taken to reach full body size. For instance, the maximal duration of human life is about 100 years which is about five times the period taken to reach full body weight and height. There are, of course, individual and species variations in this respect. This maturation principle seems to apply to business. Often businesses which grow quickly, decline quickly, while slowly developed organizations may face a slow decline and lingering death!

Of course, various other factors affect this growth/ageing relationship. For example, in animals and humans there is a nutritional relationship between the rate of growth and the rate of ageing. In experiments on rats it has been shown that richly fed rats (rapidly maturing) live a shorter period than underfed (slowly maturing) rats. Insurance companies are well aware of the lower life expectations of overfed adults! The significant point is that while underfeeding involves serious hazards, these are not as great as overfeeding. Relating this to the business organization, one can suggest that businesses which incur 'organizational slack' or 'fatness' (high expense ratios, an easy work rate, over-departmentation, over-stocking, etc.) will face an early death as profits slide. Conversely, a tightly-run business without 'excessive plumpness' has a greater chance of longer survival.

Exactly when a slowing up of growth takes place, can be determined (and possibly prevented) by analysing the growth-inhibiting factors both within the organization and in the environment. For example, a sales organization may find that growth proceeds in a geometric progression (as discussed earlier) and then suddenly starts slowing. Thi slow-down reflects the intrusion of a critical factor and sug gests a need to take a complete relook at marketing strateg and structure and the need for vigorous action such : employing additional sales staff, giving more sales trainin boosting advertising expenditure, introducing new produc 
decentralization, or whatever approach is appropriate.

\section{The growth curve - a pointer to the future}

The Sigmoid growth curve is an inexorable fact of life, business or otherwise. It is a mathematical representation of a natural phenomenon that should not be ignored by the business or marketing man. The surprising thing is that it is used so little. Perhaps because it is so little understood.

No one, of course, is saying that the issues involved are straightforward. There are many different reasons why the growth of a business (or product) slows and ageing takes place and any number of 'critical factors' can affect the outcome, e.g. availability of resources and resource utilization, communication breakdown, environmental factors - social, political, economic - competitive action, supply restrictions, and so on.

The interesting point though is even if there are no 'critical factors', the company still ages - in much the same way that man ages irrespective of whether his environment is hostile or benign. (Of course, a hostile environment hastens the ageing process.)

The 'growth phenomenon' tells us that the eventual decline of a business is inevitable from a combination of evolutionary necessity related to the 'survival of the species'; the accumulated effects of 'wear and tear'; a growing inability of the organism to adapt to the changing environment; from a homeostatic imbalance within the organization; accummulation of 'metabolic waste'; ageing of business structures and even what might be termed 'disease'.

The astonishing thing is that there are so many similarities here with nature. This suggests the need for businessmen in general, and researchers in particular, to investigate further the growth phenomenon, to look at the mechanics and mechanisms relating to growth and to put this knowledge to judicious use.

In the same way that modern medical science has prolonged the average life span of man, so too modern business research should be concerned with prolonging the life of business organizations. Perhaps there is a call to develop disciplined and co-ordinated research into business ailments, much along the lines of medical research, for example:

\footnotetext{
Medical research

Embryologist studies embryonic pe- Innovation specialist studies the riod of growth and the mechanisms 'innovation idea' and forwards it to that make the embryo grow, and fruition. Steers the company how to modify it.
}

Cytologist and histologist studies the Organization and methods manager structure and function of individual makes an analytical assessment of cells in growth and how growth organization structure and function, occurs by cell division, cell enlarge- how growth occurs by divisionalizament, differentiation and so on. tion, division enlargement, differentiation, and so on.

Morphologists are concerned with The 'mergers specialist' is concerned problems of organization, with the with opportunity areas, with the way different kinds of cells are pro- way different kinds of businesses are duced, assembled into different assembled into organizations of a organs, and developed into bodies new shape or form. of different shape or form.

The cancer specialist studies the The labour relations officer prevents mechanisms whereby some cells problems from flaring up in an unflare up in an uncontrolled manner, controlled manner: wild cat strikes, over-running, choking and finally labour discontent and slow downs, killing the body. etc. which cause financial loss.

It could well be that marketing and market research could benefit from becoming, in a sense, truly inter-disciplinary, of learning the lessons provided by the thousands of manhours spent on research in other fields, rather than remaining in its own 'propitious niche'. Perhaps there is a need for wider horizons. After all, growth is a universal phenomenon and an understanding of the fundamental concepts underlying growth is certainly a worthwhile pursuit.

\section{References}

1. Allen, L.A. The Management Profession. New York: McGrawHill, 1964.

2. Amiel, H-F. (1821-1881). French Poet. Source of quotation unknown to author.

3. Fichte, J.G. (1762-1814). German philosopher. Author of numerous publications including his Wissenschaftslehre (1797) from which quotation taken. See Stroll, A. \& Popkin, R.H., Introduction to Philosophy. New York: Holt, Rinehart and Winston; 1962.

4. Bowden, G.C.F.M. Matthias Alexander and the Creature Advance of the Individual. London: Camelot Press, 1965.

5. Chandler, A.D. Jnr., Strategy and Structure. Cambridge, Massachusetts: The M.I.T. Press, 1962.

6. Heidegger, M. Being and Time. Translated by J. Macquarrie and E.J. Robinson. Harper and Row: New York, 1962.

7. Levitt, T. Innovation in Marketing: New Perspectives for Profit and Growth. New York: McGraw-Hill, 1962.

8. Brody, S. Bioenergetics and Growth. New York: Reinhold Publishing Corp., 1945.

9. Flippo, E.B. Personnel Management. (5th ed.) Tokyo: McGraw-Hill, 1980, p.63.

10. Reddin, W.J. Managerial Effectiveness. New York: McGrawHill, 1970. See also Fiedler, F.E. A Theory of Leadership Effectiveness. New York: McGraw-Hill, 1970; Blake, R. \& Mouton, J. Managerial Grid. Houston: Gulf Publishing Co., 1964.

11. Peter, L.J. \& Hull, R. The Peter Principle. New York: William Morrow and Company, 1969. 